\title{
Are Canadian Schools Ready to Code?
}

doi:10.18162/fp.2017.a129

\section{HRONIQUE • Technologies en éducation}

\section{Introduction}

From coast to coast, more and more Canadian students are learning how to code. British Columbia ${ }^{2}$ and Nova $\mathrm{Scotia}^{3}$ are spearheading the way, having introduced coding classes in September 2016. But this movement is hardly confined to the shores of Canada and North America. In France, teachers can teach coding as early as kindergarten, ${ }^{4}$ and students in the United Kingdom have been coding since 2014. In 2013, schools across the United States ${ }^{5}$ and Sweden ${ }^{6}$ started including Minecraft ${ }^{7}$ in the curriculum so that students could learn coding by gaming. Estonia was one of the first pioneers in this sense, having introduced coding into their schools in 2012.

Is coding the latest Copernican Revolution at school? Well, it just might be. Coding is so popular that droves of students from around the world come together once a year at the Hour of the Code ${ }^{8}$ in December. Millions of students from 180 countries gather in a virtual coding celebration, proving that anyone can do it. This is the single biggest school event ever held. ${ }^{9}$ It is a genuine revolution: a coding revolution.

Nevertheless, even though students love to code, there are naysayers who stand firmly against it. They cite logistical or technical reasons, or the argument that schools should fiercely guard their independence from "big technology,' which has taken a keen interest in this new opportunity. ${ }^{10}$ We should also ask ourselves if coding is an accessible skill for all students across the board. First and foremost, however, we should understand something about what it means to learn to code, and what the benefits are. 


\section{What does learning how to code mean?}

Learning how to code means learning how to program a computer. This know-how is required to operate a vast array of devices that we use every day, for example:

- Cell phones

- Word processing software

- $\quad$ Social networking sites (Facebook, Twitter)

- Video games

- Toys

- etc.

Learning to program means learning how to instruct a machine, a software program, a Web page, or other such item what to do under specific conditions or circumstances. We are surrounded by such programs every day, in almost all situations, so shouldn't we know at least the basics of how they work? By learning how to code, we gain some small understanding of the world we live in, and therefore, we are somewhat more prepared to occupy it.

\section{Tools and resources for learning to code}

There are many tools available to help students learn to code. For example, software programs such as Swift Playgrounds ${ }^{11}$ which is one of the best apps for learning to code. It is free and also has one of the most appealing interfaces. It's easy to use, and students can track their coding progress on the screen. There is Scratch ${ }^{12}$ (and ScratchJr for younger children). They are fun games that are available free of charge. They initiate youngsters into coding, with the added bonus of teaching them math and computing. They use simplified programming languages that children can apply to create video games, interactive stories, and animated drawings. They snap together graphical programming blocks and modify them to make scenes and characters come to life. They can follow a teacher-designed lesson or make up their own scenarios, like real programmers and directors. As they develop programming and logical skills, they are exercising their creativity. Coding allows them to organize their thinking as they write and act in their own stories. To do so, they use reading, writing, counting, original expression, and more.

Another example is the code.org site. A beacon for inclusive education, it is a non-profit organization dedicated to expanding access to computer science, for every student, in every school. The site offers a wide range of free computer science courses to teachers and students, and it organizes the annual Hour of the Code campaign.

\section{What are the educational benefits of learning to code?}

To identify and better understand the benefits of learning to code at school, we conducted an exploratory study in five elementary schools that included coding in their curriculum from kindergarten to Grade 6. After four days of observation, we found that students who used Scratch, ScratchJr, and Minecraft ${ }^{13}$ 
showed motivation, enthusiasm, and ability to concentrate, and this was particularly evident in students who tended not to show these attributes during traditional lessons.

We also held interviews with the students and teachers to gather their perspectives on learning to code in class. The results of this preliminary study showed that learning to code brings a number of benefits in terms of cognitive and affective functioning. We identified a total of 40 positive impacts. The first, emphasized by both teachers and students, was improved academic motivation. But there were plenty of positive impacts in other areas as well:

- Students' feelings of competence and self-esteem

- Mathematics learning

- Problem solving

- Autonomy

- Teamwork and mutual assistance

- Structured thinking

- Risk taking

- Organizational and planning skills

- First language learning

- Computer science skills

- Sharing accomplishments, discoveries, etc.

Furthermore, the students especially liked how the coding app let them work at their own pace, as well as the instant feedback, "without feeling judged." They appreciated how it "let me see what I understand right away $[\ldots]$ and what I don't $[\ldots]$ so it's easier to learn.”

For the teachers, it was a way for their students to have fun while developing diverse skills. They also realized that coding in class let them use differentiated instruction, because not only could their students learn at their own pace, they could also complete coding projects at their individual skill levels: "All the students managed to learn how to code $[\ldots]$ from kindergarten to Grade $6[\ldots]$." And this was "regardless of their learning problems," and regardless of socioeconomic status.

Nevertheless, despite all these benefits, we also noted some challenges involved in learning to code at school.In order to provide optimal conditions for the coding lessons and to ensure success, the following elements need to be in place: appropriate teacher training, adequate pedagogical and technical support, properly working coding equipment (tablets, computers), and support by the school administration.

It is noteworthy that some of the students at the schools in this study were recent immigrants. The use of coding software had a strong impact on these students: in addition to stimulating peer interactions through shared experiences and mutual assistance, the coding exercises motivated students with learning problems and encouraged them to be more engaged at school. In this case, the computerized support appeared to foster both sharing and empowerment. As mentioned above, the students showed improved self-esteem after learning to code, and students with learning problems found themselves working side-by-side with their classmates and taking pride in their productions. There can be little doubt that these experiences will lead to better integration at school and in society. 


\section{Conclusion}

This project appears to have been a smashing success as far as both teachers and students were concerned. The students were delighted to learn how to code, and they had a lot of fun doing it. As they grow up and appropriate ever more complex digital devices, they may look back on this initiation as the first time they had the feeling of mastering their computerized surroundings. Hopefully, many will go on to make technology breakthroughs and carve out new and unimagined careers. Finally, if you would like to try coding with your students, we compiled a list of the 11 best coding apps for any teacher to use and share ${ }^{14}$.

\section{Notes}

1 The pilot study was conducted in 5 elementary schools. Participants included 23 teachers and 697 students aged 5 to 12 years.

2 http://ecolebranchee.com/2016/02/22/les-eleves-de-la-colombie-britannique-apprendront-a-coder/

3 http://ici.radio-canada.ca/regions/atlantique/2015/10/21/016-codage-informatique-programmation-education-ne-ecoles. shtml

$4 \mathrm{http} / /$ www.cnetfrance.fr/news/programmation-a-1-ecole-les-eleves-francais-apprendront-a-coder-des-la-rentree-201639837908.htm

5 https://www.washingtonpost.com/lifestyle/kidspost/minecraft-spawns-classroom-lessons/2013/03/14/717aed66-87b8-11e2 98a3-b3db6b9ac586_story.html

6 http://www.pcgamer.com/minecraft-becomes-a-compulsory-class-for-swedish-school/

https://minecraft.net/fr/

https://hourofcode.com/fr

https://hourofcode.com/files/schools-handout.pdf

Bihouix, P. et Manvilly, K. (2016). Le désastre de l'école numérique : Plaidoyer pour une école sans écrans. Paris : Seuil.

https://itunes.apple.com/us/app/swift-playgrounds/id908519492?mt=8

https://scratch.mit.edu/

https://minecraft.net/fr/

$\underline{\text { http://karsenti.ca/11coding.pdf }}$

\section{Pour citer cet article}

Karsenti, T. \& Bugmann, J. (2017). Are Canadian Schools Ready to code. Teachers and teaching, 25(2), 111-114. http://dx.doi.org/10.18162/fp.2017.a129 